\title{
SOME ASPECTS OF THE MANAGEMENT OF UNLICENSED CROWN LAND NEAR SETTLEMENTS IN NEWFOUNDLAND
}

\author{
BY D. E. NICKERSON 1
}

During the summer of 1950, the Forestry Branch of the Department of Resources and Development of the Federal Government carried out in Newfoundland a project entitled "Assessment of the Bonavista Peninsula Forestry Problem." This project has aroused the interest of the Farm Woodlot Management Committee of the Canadian Institute of Forestry, because some of the problems involved may yield to methods used in orthodox farm woodlot management. The subject is the more intriguing by virtue of the fact that we are not dealing here either with farms or woodlots in the usual sense, but with small communities which make direct use of the forest on nearby Crown lands.

The forest on a three-mile strip of land around the coast of Newfoundland is reserved for the use of small coastal communities. This strip of land and the Bonavista Peninsula are unlicensed Crown lands. Prior to 1939, anyone living within this strip could cut forest growth anywhere and at any time without special permission, and without paying any stumpage, except in the case of pit-props and pulpwood cut for export.. Free cutting permits must now be obtained to cut sawlogs on these unlicensed Crown lands, while the cutting of pulpwood, pit-props and railway ties is not allowed, although under 1950 legislation special permits may be obtained in exceptional circumstances. Fuelwood may still be cut at will. The only revenue now received by the Government from these lands comes in the form of sawmill licences. Mills are small and there are approximately one thousand scattered around the coast.

Since the work of the Forestry Branch of investigating local forest conditions has been confined thus far to the Bonavista Peninsula, no further attempt at broad generalization will be made. Field work was carried out under the direction of Messrs. H. S. Lewis and W. C. Wilton, of the Newfoundland District Office during the summer of 1950, and they have since prepared a full report. Detailed studies of the natural supply areas for five representative settlements were carried out, rough estimates of increment in various classes of material were made, and data on drain were obtained locally. Information on a variety of other subjects, such as forest products, Iand ownership, cutting methods, etc., was also collected.

The forest on the Peninsula consists almost entirely of black spruce and balsam fir, 40 to 60 years of age. This is the result of an extensive fire which swept the length of the Peninsula in 1892. More recent fires have completely denuded extensive areas near the eastern tip. Eastern larch, white birch and trembling aspen occur as minor species. The diameter growth of spruce and fir is excellent on most sites and commonly amounts to two inches in 10

1 District Forest Officer, Forestry Brnneh, Department of Resources and Development, St. John'в, Newfoundland. 
years. Height growth of small trees is also excellent, but there are indications that ultimate height development will seldom exceed 40 feet.

Two of the settlements were classified by Messrs. Lewis and Wilton as being fishing communities, while the other three, although originally fishing communities, were classified as lumbering communities. The forest near the two fishing communities ${ }^{2}$ was found to be in much better condition than the forest near the communities where the local populace has transferred almost its entire interest to lumbering.

Since the supply of logs near the lumbering communities is depleted, the tendency is for the more successful lumbermen to transfer their efforts to the forest adjacent to communities where the inhabitants have shown little interest in lumbering. Road construction and a heavy demand for fuelwood have contributed to this pressure on the remaining uncut stands, but the current price for rough-sawn, ungraded lumber presents a strong incentive to any local businessman. The old idea of an extensive Crown forest free to all is difficult to reconcile with these modern pressures.

The situation in one typical lumbering community will be cited here to illustrate both the main problems of the Bonavista Project and the plight of one community containing 83 families dependent on nine small sawmills. There are approximately 500 acres of private land in the community, of which 300 have been cleared, the remaining 200 consisting of pasture and dense reproduction. Mr. Lewis, who carried out the study in this particular community, concluded that the local mills obtain their supplies of logs from an over-all area of 8170 acres, 77 per cent of which he classes as productive forest land.

The average stand per acre of spruce and fir 5.6 inches and larger at breast height is 500 f.b.m., while the average stand per acre 3.6 inches to 5.5 inches at breast height is $190 \mathrm{cu}$. $\mathrm{ft}$. The average stand per acre of birch and poplar 5.6 inches at breast height and up is $30 \mathrm{cu}$. $\mathrm{ft}$. The average dimensions of sawlogs obtained in 1950 were 6.7 inches at the butt, 4.6 inches at the top, and 10.7 feet in length.

Fuelwood is taken from the four and five inch d.b.h., classes with a decided preference for spruce. Entire stands of young growing stock are liquidated each year in order to save time in obtaining the year's supply. Birch is taken only when it is present in stands of spruce being cut for fuelwood.

Severe cutting for pulpwood and pit-props during the depression years reduced the available timber supply to a low level. In more recent years the cutting of pulpwood and pit-props has ceased, but an increase in the price of lumber has brought about an intensified search over the area for sawlogs. This search extends to almost every acre each year.

Despite the above conditions, the $372 \mathrm{M}$ bd. ft. of sawlogs harvested in 1950 was only slightly in excess of the estimated increment of $340 \mathrm{M} \mathrm{bd}$. ft.,

\footnotetext{
2 It should not be assumed that all fishing communities are as well supplied with forest reserves as the two sampled. Many communities occur in non-forested areas, and must obtain fuelwood and other products from some outside source. The town of Bonavista (5000 in habitants) at the extreme tip of the Peninsula falls into this category.
} 
while the estimated increment for material below sawlog size, $144,000 \mathrm{cu}$. ft., was well in excess of the fuelwood cut of $73,000 \mathrm{cu}$. $\mathrm{ft}$. Balsam fir reproduction is abundant and dense, stagnant fir thickets are not a serious problem.

One can only conclude that from a forestry standpoint this settlement has reached an unenviable condition, even though apparent increment and drain are not far out of line. Sawlog sizes cannot be reduced much further, cuts cannot be made more often than once a year, and while a cut comparable to the present might conceivably be continued for some years, the continued cutting of the best spruce poles for firewood must result in still further lowering $\log$ quality. In other words it is apparent that the sawlog industry in this community is dependent for its existence on an abnormally high price for lowgrade lumber.

The report does not pretend to offer a solution for the problem presented above. The obvious answer is to leave the forest alone for a few years and let the trees grow but what of the needs of the local populace? Instead, the report suggests certain methods of handling stands on the Bonavista Peninsula so that they will not continue to deteriorate, and includes two recommendations.

One recommendation is to the effect that the Forestry Branch should demonstrate practical cutting methods on a managed woodlot. The Provincial Government has made 90 acres of suitable forest available and this woodlot is now being established.

The other recommendation is "that the Provincial Government investigate the possibilities of fostering a sense of proprietorship and responsibility toward the forest by the local populace, the ultimate aim of such investigations to be the establishments of community forests, or some other form of local forest control."

If some suitable form of local proprietorship can be devised and introduced, the foundation will be laid for extension forestry as we know it. Until that time, regardless of regulations, it is not believed the local people can be expected to be greatly interested in growing trees for their neighbours or for the lumberman from the next settlement. 